\title{
Estimation of cerebrospinal fluid protein
}

\author{
C. A. PENNOCK ${ }^{1}$, L. P. PASSANT, AND F. G. BOLTON \\ From the Department of Pathology and the Nuffield Department of Clinical Biochemistry, \\ United Oxford Hospitals
}

SYNOPSIS Three turbidometric methods and one method using ultraviolet spectrophotometry for estimating total cerebrospinal fluid protein have been examined. The necessity for preliminaryo dialysis renders the ultraviolet method unsuitable for routine use.

The turbidometric method of Meulemans (1960) using a sulphosalicylic acid-sodium sulphates precipitating fluid is better than a method using sulphosalicylic acid alone which is affected by the albumin-globulin ratio, and has a greater sensitivity and better reproducibility than a method $\frac{r}{\infty}$ using trichloracetic acid as a precipitant. Turbidity may be measured with a spectrophotometero or an MRC grey wedge photometer with human or bovine albumin as a standard. This method deserves wider acceptance.

It is important that the method for estimating total protein in cerebrospinal fluid should be both simple and accurate. We have examined three turbidometric methods and an ultraviolet spectrophotometric method, all of which are simple, in order to determine their accuracy.

\section{METHODS}

Samples of cerebrospinal fluid received in a routine clinical pathology laboratory from patients with various neurological disorders were used in this study. The volume was not always sufficient to carry out all the tests under investigation.

Ultraviolet spectrophotometric estimation of protein was carried out on $0.1 \mathrm{ml}$ of cerebrospinal fluid diluted 1 in 50 with physiological saline. The absorption at $210 \mathrm{~m} \mu$, the wavelength at which extinction of proteins in solution is due to the peptide bonds (Goldfarb, Saidel, and Mosovich, 1951), was recorded with a $1.4 \mathrm{~mm}$ slit width using $1 \mathrm{~cm}$ silica cuvettes in an Unicam S.P. 500 spectrophotometer with saline as blank (Tombs, Souter, and Maclagan, 1959).

The protein in $1 \mathrm{ml}$ of cerebrospinal fluid was precipitated with $3 \mathrm{ml}$ of $3 \%$ sulphosalicylic acid (Yeoman, 1955 ), or with $3 \mathrm{ml}$ of $3 \%$ sulphosalicylic acid in $7 \%$ sodium sulphate or with $3 \mathrm{ml}$ of $3 \%$ trichloracetic acid (Meulemans, 1960). The turbidity was recorded after 10 minutes in a $1 \mathrm{~cm}$ cuvette at $680 \mathrm{~m} \mu$ (S.P. 500 spectrophotometer) with distilled water as a blank or in an MRC grey wedge photometer. A human albumin solution was used as a standard for the sulphosalicylic acid/sodium sulphate, trichloracetic acid and ultraviolet

'Present address: Department of Chemical Pathology, Bristol Royal Infirmary, Bristol, 2.

Received for publication 3 November 1967. estimations. Sulphosalicylic acid estimations were made direct from MRC photometer readings previouslyo calibrated for total protein (Yeoman, 1955).

Turbidometric and ultraviolet spectrophotometrics estimations were made on several samples of CSF before and after dialysis against physiological salinę for 18 hours at $4^{\circ} \mathrm{C}$ in $8 / 32$ Visking ${ }^{1}$ tubing and on several dialysed samples before and after the addition of known amounts of albumin. The albumin content of samples of cerebrospinal fluid was determined by electro-3 phoresis on cellulose acetate membrane after preliminary? concentration. The membranes were stained with $0.5 \%$ light green and scanned by reflectance densitometry.

Samples of cerebrospinal fluid were tested for fibrinogeno content by the slide coagulase test (Cadness-Graves, Williams, Harper, and Miles, 1943) capable of detecting 10 to $12 \mu \mathrm{g}$ per $100 \mathrm{ml}$ (Duthie, 1955) and by a gelo diffusion technique capable of detecting $500 \mu \mathrm{g}$ perร $100 \mathrm{ml}$ of fibrinogen (Allington, 1965) using an absorbed rabbit antihuman fibrin serum prepared by the method of Ferreira and Murat (1963) and kindly provided by Dr M. J. Allington, Radcliffe Infirmary, Oxford.

\section{RESULTS}

ULTRAVIOLET ABSORPTION The extinction coefficientsw at $210 \mathrm{~m} \mu$ of solutions of human albumin gamma globulin, and fibrinogen and of bovineo albumin are shown in Table I. The diluent wasD saline except for fibrinogen which was incompletely. soluble in saline and was dissolved initially in 눈 $40 \%$ urea in $0.2 \mathrm{M}$ sodium chloride and subse을 quently diluted in saline. A similar dilution of alkaline urea in saline was used as a blank. Beer $\mathbb{R}_{\mathbb{Q}}$ law was obeyed by all solutions over the opticato ${ }^{1}$ Hude's Merchandising Corp. 
TABLE I

RESULTS IN PRESENT SERIES COMPARED WITH OTHER SERIES ${ }^{1}$ $\begin{array}{lll}\text { Present }^{\text {Work }}{ }^{2} & \begin{array}{l}\text { Goldfarb Tombs } \\ \text { et al }\end{array} & \text { et al }\end{array}$ (1951) (1959)

Human albumin Human albumin (in alkaline urea) Bovine albumin

Human globulin

Human fibrinogen (in

alkaline urea)

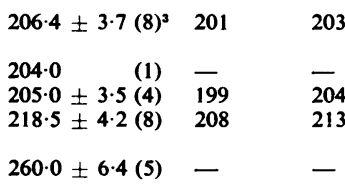

${ }^{1}$ All proteins were dissolved in saline except where otherwise stated. ${ }^{2}$ Results from the present work are shown as E $1 \% / 1 \mathrm{~cm} \pm 1 \mathrm{SD}$. Number of estimations in parentheses.

density range 0.05 to 1.8 (ie approximately 12 to $440 \mathrm{mg}$ protein per $100 \mathrm{ml}$ ). Thirteen of 20 samples of cerebrospinal fluid $(65 \%)$ tested for fibrinogen by the slide coagulase test gave a positive result but only two of these, both contaminated with blood, gave a positive result by the gel diffusion technique. Therefore the concentration of fibrinogen, except in bloodstained samples, was less than $500 \mu \mathrm{g}$ per $100 \mathrm{ml}$. Although fibrinogen has a higher extinction coefficient than albumin or globulin it is unlikely to affect the estimation of total protein when present at this low concentration.

Cerebrospinal fluid samples dialysed against saline showed a marked but variable reduction in ultraviolet readings (from 6 to $88 \%$ ) after dialysis but little change by turbidometric methods. More prolonged dialysis did not reduce the ultraviolet readings further. The low readings after dialysis corresponded with the protein concentrations determined by sulphosalicylic acid/sodium sulphate.

TURBIDOMETRIC METHODS Standard solutions of human albumin and human gamma globulin gave the same turbidity with sulphosalicyclic acid/sodium sulphate or trichloracetic acid whereas there was nearly a fourfold increase in the turbidity of albumin compared with gamma globulin with sulphosalicylic acid as precipitating fluid. In a series of solutions of the same total protein concentration but with increasing proportions of albumin there was an increase in apparent protein concentration by sulphosalicylic acid whereas by sulphosalicylic acid/sodium sulphate or trichloracetic acid there was little change (Fig. 1). Similar results were obtained when albumin was added to dialysed cerebrospinal fluid.

With all three turbidometric methods there was a progressive increase in density with time reaching a maximum after 10 minutes and therefore all turbidities were read at a standard time of 10 minutes. To investigate the effect of temperature, the protein

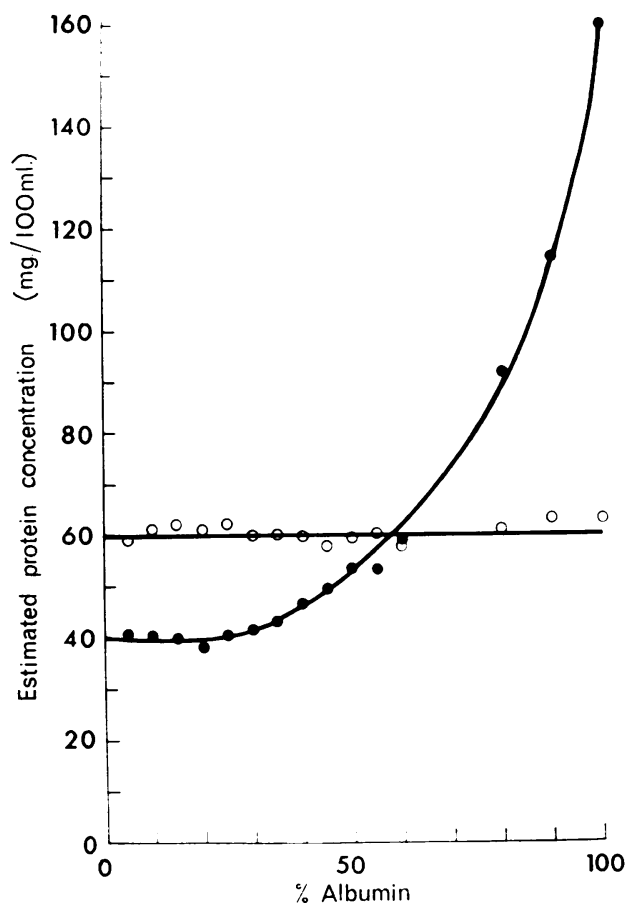

FIG. 1. Effect of $\%$ albumin in a solution of constant total protein content on estimation of protein with sulphosalicylic acid (O) and sulphosalicylic acid/sodium sulphate $(\bigcirc)$.

in six samples of cerebrospinal fluid (range 60 to $140 \mathrm{mg}$ protein per $100 \mathrm{ml}$ ) was precipitated with sulphosalicylic acid/sodium sulphate at $4,22,37$, and $44^{\circ} \mathrm{C}$ and the turbidity was expressed as a percentage of the turbidity at $22^{\circ} \mathrm{C}$. There was a linear relationship between turbidity and temperature and the temperature coefficient was $1 \%$ per degree centigrade (Fig. 2). Therefore all precipitations were done in a water bath at $22^{\circ} \mathrm{C}$. A similar temperature dependence was found for sulphosalicylic acid or trichloracetic acid.

Twenty estimations of turbidity by sulphosalicylic acid, sulphosalicylic acid/sodium sulphate, and trichloracetic acid methods on a bulk pooled sample of cerebrospinal fluid (protein concentrations $55 \mathrm{mg}$ per $100 \mathrm{ml}$ ) gave coefficients of variation for sulphosalicylic acid $2.7 \%$, sulphosalicylic acid/ sodium sulphate $3.15 \%$, and for trichloracetic acid $7 \cdot 45 \%$. Trichloracetic acid gave about half the turbidity of sulphosalicylic acid/sodium sulphate. Because of the lower sensitivity and poor reproducibility of trichloracetic acid and the effect of the percentage of albumin on sulphosalicylic acid these two methods were considered unsuitable. 


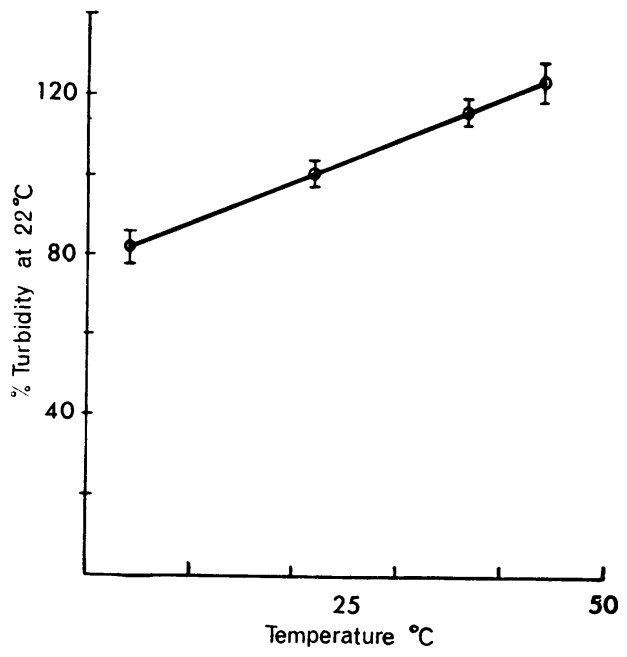

FIG. 2. Effect of temperature on turbidity by the sulphosalicylic acid/sodium sulphate method. Results are shown as a percentage of the turbidity produced at $22^{\circ} \mathrm{C} \pm$ $1 S D$.

COMPARISON OF ULTRAVIOLET AND TURBIDOMETRIC METHODS The protein concentration of 18 samples of cerebrospinal fluid was estimated by sulphosalicylic acid/sodium sulphate and compared with an ultraviolet estimate on the same samples after dialysis. Correlation was highly significant $(r=$ $0.9986, P<0.001)$; the equation of the regression line was $y=3.4+x$. There was a linear relationship between total protein concentration and turbidity by sulphosalicylic acid/sodium sulphate up to a protein concentration of $250 \mathrm{mg}$ per $100 \mathrm{ml}$.

\section{DISCUSSION}

Our results confirm the observations of Henry, Sobel, and Segalove (1956) and Meulemans (1960) that an increase in the relative concentrations of albumin affects the turbidity in sulphosalicylic acid. Good correlation has been shown between Kjeldahl estimations of nitrogen and the total protein determined by this method (Yeoman, 1955; Alexander and Parkes, 1959) and we can only assume that the albumin/globulin ratio was fairly constant in the samples examined. We have found abnormal samples with high albumin content giving falsely high results by sulphosalicylic acid turbidometry but not by sulphosalicylic acid/sodium sulphate turbidometry.

It has been demonstrated that the absorption of protein solutions at 205 to $210 \mathrm{~m} \mu$ is mainly due to the peptide bonds and thus different proteins have similar extinction coefficients at this wavelength (Goldfarb et al, 1951). Estimation of protein in cerebrospinal fluid at slightly higher wavelengths has been described by Waddell (1956) and Watson (1964). Many substances interfere at these wavelengths (Tombs et al, 1959) but our results show that interfering small molecules can be removed by dialysis, and that the lower readings obtained correspond with the protein concentration estimated by sulphosalicylic acid/sodium sulphate turbidometry. However, the necessity for preliminary dialysis renders ultraviolet methods unsuitable for routine use.

Micro-Kjeldahl estimations are difficult to carry out and unsuitable for routine use, while colorimetric methods have errors due to interfering substances (Rice and Loftis, 1962). Trichloracetic acid precipitation is not affected by the albumin/globulin ratio but its accuracy is not very high (Henry et al, 1956) and reproducibility is poor.

The turbidometric method of Meulemans (1960) using a solution of $3 \%$ sulphosalicylic acid in $7 \%$ sodium sulphate would thus appear to be the method of choice for routine use as it is unaffected by changes in albumin/globulin ratio and the turbidity can be read after 10 minutes. Turbidity is unaffected by the use of saline as a diluent. Like sulphosalicylic acid and trichloracetic acid methods (Schriever and Gambino, 1965) it is affected by temperature; precipitation of protein in cerebrospinal fluid and in standard protein solutions should be done at the same temperature. We have found bovine albumin suitable as a standard; solutions may be kept for one month at $4^{\circ} \mathrm{C}$ and the total protein checked by the ultraviolet method. Webelieve that this method provides a reliable and simple means of estimating total protein concentrations and deserves wider acceptance.

We wish to thank $\mathrm{Mr}$ J. R. P. O'Brien, Nuffield Biochemist, for the facilities provided by his department and Miss Françoise Vionnet for technical assistance.

\section{REFERENCES}

Alexander, J. G., and Parkes, J. (1959). J. clin. Path., 12, 91 Allington, M. J. (1965). Thesis, University of Oxford, pp. 45-54. Brackenridge, C. J. (1962). J. clin. Path., 15, 206.

Cadness-Graves, B., Williams, R., Harper, G. J., and Miles, A. A. (1943). Lancet, 1, 736

Duthie, E. S. (1955). J. gen. Microbiol, 13, 383.

Ferreira, H. C., and Murat, L. G. (1963). Brit. J. Haemat., 9, 299. Goldfarb, A. R., Saidel, L. J., and Mosovich, E. (1951). J. biol. Chem. 193, 397.

Henry, R. J., Sobel, G., and Segalove, M. (1956). Proc. Soc. exp. Biol. (N.Y.), 92, 748.

Meulemans, O. (1960). Clin. chim. Acta, 5, 757.

Rice, E. W., and Loftis, J. W. (1962). Clin. Chem., 8, 56.

Schriever, H., and Gambino, S. R. (1965). Amer. J. clin. Path., $44,667$.

Tombs, M. P., Souter, F., and Maclagan, N. F. (1959). Biochem. J. 73, 167.

Waddell, W. J. (1956). J. Lab. clin. Med., 48, 311

Watson, D. (1964). Clin. Chem., 10, 412.

Yeoman, W. B. (1955). J. clin. Path., 8, 252. 